\title{
EFFECT OF SEAWEED EXTRACT AND PLANT SPACING ON GROWTH AND YIELD OF TWO EGGPLANT HYBRIDS (SOLANUM MELONGENA L.)
}

\author{
SANAA M.S RASHEED and REZAN S. SHAREEF \\ Dept. of Horticulture, College of Agricultural Engineering Sciences, University of Duhok, \\ Kurdistan Region-Iraq
}

(Received: July 28, 2019; Accepted for Publication: October 20,2019)

\begin{abstract}
The experiment was conducted at the vegetable research farm, College of Agricultural Engineering Sciences, University of Duhok, Iraq, in the growing season (2018) to study the effect of seaweed extract at four concentrations $(0,0.5,1.0$, and $1.5 \mathrm{ml} / \mathrm{L})$ and plant spacing at three levels $(30,45$ and $60 \mathrm{~cm})$ on growth and yield of two eggplant (Solanum melongena L.) cultivars. The seaweed extract (Tecamin algae) sprayed at three times during growing season, 15 days between each spraying and another. The experiment were designed in a factorial experiment within Split-Split-Plot Design in (RCBD), with three replication. The results showed that the seaweed extract at concentration $\left(1 \mathrm{ml}^{-1} \mathrm{l}^{-1}\right)$ significantly increases leaf area $\left(\mathrm{cm}^{2}\right)$, leaf chlorophyll content, average fruit weight, plant yield (Kg.plant $\left.{ }^{-1}\right)$ and total yield $\left(\right.$ ton.ha $\left.^{-1}\right)$ compared with control plants, but not affected on plant height. Plant spacing at level $(30 \mathrm{~cm})$ significantly increased plant height and total yield, whereas at level $(60 \mathrm{~cm})$ significantly improved leaf area, chlorophyll content in leave and plant yield. Also, the Kyme cultivar significantly affected in average fruit weight, plant yield and total yield, while Anamur RZ cultivars increased plant height. The binary and triple interaction revealed that the combination between Kyme cultivars, plant spacing at level (60

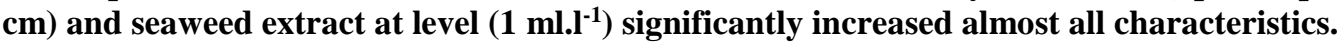

https://doi.org/10.26682/ajuod.2019.22.2.11

\section{INTRODUCTION}

$\mathbf{E}$ ggplant (Solanum melongena L.), is a popular vegetable also known as Brinjal (India), Aubergine (United Kingdom), or Guinea squash (Southern of United States) and it is one of the commonly grown species in the family Solananceae (Kantharajah and Golegaonkar, 2004). It is one of the major crop an economically in Africa, Asia and in almost all sub-tropics and is also grown in some warm temperate regions of the South America and Mediterranean (Das et al., 2010). Eggplant is intolerant to frost, and the growth of small plants will be slow down when night temperatures are less than $16^{\circ} \mathrm{C}$ ( Chen And Li, 2000).

The yield production depends on several factors, from these proper and balanced nutrition plays an effective role (Bozorgi, 2012). One of the most effective nutrition ways is the use of seaweed extract. Seaweeds include the multicellular and macroscopic marine algae that usually lived in the coastal regions of the world's oceans where suitable habitat exist (ElMiniawy et al., 2014). Seaweed extract application for various crops has a considerable benefits as a results to its content with high amounts of organic matter, micro elements $(\mathrm{Cu}$, $\mathrm{Fe}, \mathrm{Co}, \mathrm{Zn}, \mathrm{Mn}, \mathrm{Mo}$, and $\mathrm{Ni}$ ), amino acids and vitamins and also, it is a good sources of growth regulators such as auxins, gibberellins and cytokinins (Khan et al.,2009). In general, seaweed extracts, at low concentrations, are able to induce a group of physiological plant responses, such as encourage of plant growth and improvement of flowering and yield (Battacharyya et al., 2015).

Plant spacing is a significant agronomic factor that is supposed to have an effects on light interception to plant for photosynthesis which is the medium for energy producing by using green parts of the plant (Ndereyimana et al., 2014). Also the plant spacing per hectare is an important to receive higher yields in brinjal. It can be achieved by using different spacing between the rows and plants (Arun, 2013). The knowledge of crop response to plants spacing provides the basis for accessing the influences of intraspecific competition (Adani et al., 1998).

In the last years, the farmers trend to use F1 hybrids varieties for cultivation in open field. The reasons behind the use of F1 hybrids varieties in open field are their capability to 
highly increase yield and more uniformity as compared to local seeds and non-hybrid varieties ( Muñoz-Falcón et al., 2008). Therefore, this research was aimed to study the effect of planting densities and foliar spraying by seaweed extract on growth and yield production of two eggplants cultivars.

\section{MATERIALS \& METHODS}

The experiment was conducted in open field conditions at the growing season 2018, at the vegetable research farm, college of Agriculture Engineering Sciences, Sumil, Duhok, Iraqi Kurdistan region. Seeds of two hybrid cultivars of eggplant were chosen during the study which are (Anamur RZ F1 and Kyme F1). Sowing of seeds started in March, $5^{\text {th }} 2018$ for both cultivars. After 49 days from sowing seeds the seedling transplanted to the permanent place in farm in April, $23^{\text {rd }}$ 2018. The seedling planted according to plant spacing factor which are (30, 45 and $60 \mathrm{~cm})$ between plants and $(0.75 \mathrm{~cm})$ between rows. The plants was irrigated by drip irrigation. The experiment consist of the effect of two eggplant hybrid cultivars (A1 = Anamur RZ F1 and $A 2=$ Kyme F1), three levels of plant spacing $(\mathrm{B} 1=30, \mathrm{~B} 2=45$ and $\mathrm{B} 3=60$ $\mathrm{cm})$ and four levels of foliar sprayings with seaweed extract $((\mathrm{C} 1=0, \mathrm{C} 2=0.5, \mathrm{C} 3=1.0$ and $\left.\mathrm{C} 4=1.5 \mathrm{ml}^{-l^{-1}}\right)$, which mean treatment with their interaction. Anamur RZ F1 is produced in Holland by Rijk Zwaan company and Kyme F1 is produced in Barcelona, Spain by Fito company. The seaweed extract that used is Tecamin algae, which depended on algae from the genus (Ascophyllum nodosum). Foliar sprayings with seaweed extract were applied three times within 15 days intervals, starting after 15 days from transplanting. The surfactant agent Tween- 80 was added to spraying solution at rate 2-3 drops per litter.

The treatments of experiment were arranged in a factorial experiment within Split-Split-Plot Design in (RCBD), including three factors . The main plot was represented by two hybrid cultivars, three planting density in sub plot and four levels of seaweed extract in sub-sub-plot. The treatments were randomly distributed by using completely randomized blocks design (RCBD). Each experimental units involves one line, with 10 plants/line as observation. The comparison between means was carried out according to Duncan's multiple range test at (0.05) level, using a SAS computerized program (SAS, 2003).

\section{Experimental Measurements: Vegetative Growth characteristics: \\ 1. Plant Height $(\mathrm{cm})$ \\ 2. Leaf Area $\left(\mathrm{cm}^{2}\right)$ \\ 3. Leaf chlorophyll content (SPAD)}

Fruit and Yield characteristics:

1. Average weight of fruit $\left(\mathrm{g}\right.$. fruit $\left.{ }^{-1}\right)$

2. Plant yield ( Kg. plant ${ }^{-1}$ )

3. Total yield (ton. ha $^{-1}$ )

\section{RESULTS \\ Vegetative growth characteristics: \\ 1. Plant height $(\mathrm{cm})$ :}

Data presented in table (1) shows that a highly significant differences between cultivars in plant height, Anamur RZ cultivars overcame Kyme cultivar in plant height which record $(80.38 \mathrm{~cm})$. Also the plant spacing significantly affected in plant height and the highest value $(76.87 \mathrm{~cm})$ was recorded in $(30 \mathrm{~cm})$ spacing. But seaweed extract recorded no significant differences on plant height.

The interaction between cultivars and plant spacing showed a significant variation among them, which was superior in Anamur RZ cultivars and $(45 \mathrm{~cm})$ plant spacing. Interaction between cultivars and seaweed extract gives superior in plant height $(81.40 \mathrm{~cm})$ in Anamur RZ cultivars and $\left(0.5 \mathrm{ml}^{-\mathrm{l}^{-1}}\right)$ of seaweed extract. Interaction between plant spacing and seaweed extract recorded a significant differences on plant height, where $(30 \mathrm{~cm})$ plant spacing and $\left(0.5 \mathrm{ml} . \mathrm{l}^{-1}\right)$ of seaweed extract (gave the best result). Interaction among three factors resulted in a significant differences on eggplant height. The maximum plant height was determined among Anamur RZ cultivar, $(45 \mathrm{~cm}$ ) plant spacing and $\left(1.5 \mathrm{ml} . \mathrm{l}^{-1}\right)$ of seaweed extract which was $(86.46 \mathrm{~cm})$, when compared to other plants. 
Table (1): Effect of cultivars, plant spacing, seaweed extract and their interaction on plant height (cm) of eggplant.

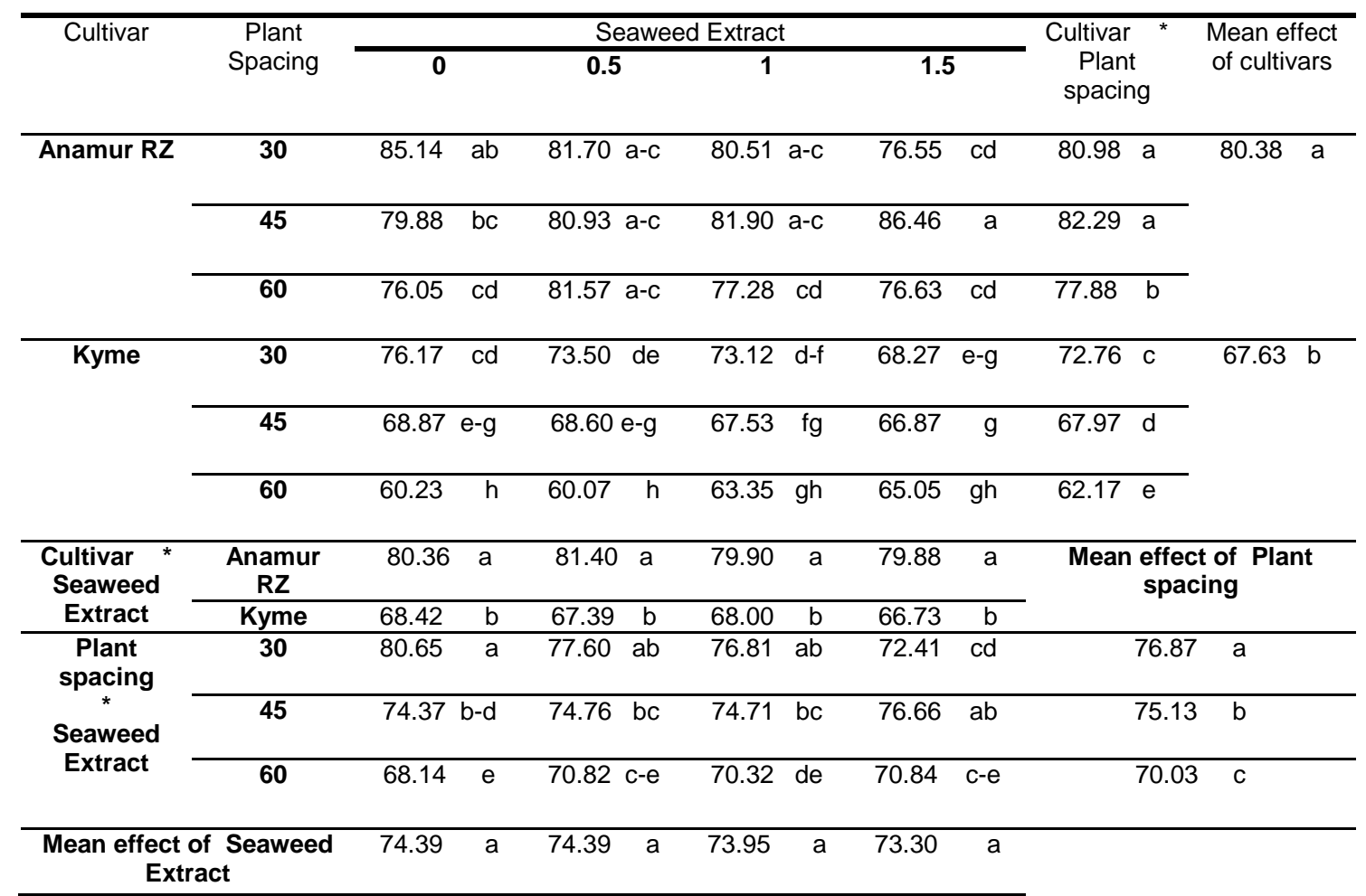

*Means within a rows, columns and their interaction written with the same letters are not significantly different from each other according to Duncan's multiple range test at $5 \%$ level.

\section{Leaf Area $\left(\mathrm{cm}^{2}\right)$ :}

Data in table (2) reported that the cultivars don't have any significant influence on leaf area of eggplant. Plants spacing significantly influenced leaf area, the maximum value obtained in $(60 \mathrm{~cm})$ spacing which was $(88.24$ $\mathrm{cm}^{2}$ ). Also seaweed extract significantly affected on leaf area, recorded the highest number $(87.70$ $\left.\mathrm{cm}^{2}\right)$ when sprayed by $\left(1 \mathrm{ml}^{\mathrm{l}^{-1}}\right)$ compared to the other plants.

In case of the interaction between cultivars and plant spacing, there were a significant variation between them, superior interaction was between Anamur RZ cultivars and $(60 \mathrm{~cm})$ spacing. The interaction between cultivars and seaweed extract gave the highest value in the combination between the Kyme cultivars and (1 ml. $\mathrm{l}^{-1}$ ) of seaweed extract. Interaction between plant spacing and seaweed extract gave a significant impact on leaf area, the best data was obtained from interaction of $(60 \mathrm{~cm})$ spacing and $\left(0 \mathrm{ml}^{-\mathrm{l}^{-1}}\right)$ of seaweed extract. Triple interaction among the factors showed a significant variation on leaf area in eggplant, the superiority was found in the interaction among Kyme cultivars, $(60 \mathrm{~cm})$ plant spacing and $\left(0 \mathrm{ml}^{-\mathrm{l}^{-1}}\right)$ of seaweed extract.

Table (2): Effect of cultivars, plant spacing, seaweed extract and their interaction in leaf area $\left(\mathrm{cm}^{2}\right)$ on

\begin{tabular}{|c|c|c|c|c|c|c|c|c|}
\hline \multirow[t]{2}{*}{ Cultivars } & \multirow{2}{*}{$\begin{array}{c}\text { Plant } \\
\text { spacing }\end{array}$} & \multicolumn{4}{|c|}{ Seaweed Extract } & \multirow{2}{*}{\multicolumn{2}{|c|}{$\begin{array}{c}\text { Cultivar * } \\
\text { Plant } \\
\text { spacing }\end{array}$}} & \multirow{2}{*}{$\begin{array}{l}\text { Mean effect of } \\
\text { cultivars }\end{array}$} \\
\hline & & 0 & 0.5 & 1 & 1.5 & & & \\
\hline \multirow[t]{3}{*}{ Anamur RZ } & 30 & 81.59 ef & $78.80 \mathrm{f}$ & $85.3 c-e$ & $78.50 \mathrm{f}$ & 81.05 & C & $85.88 \mathrm{a}$ \\
\hline & 45 & 88.25 b-d & 89.3 a-c & $87.81 \mathrm{~b}-\mathrm{d}$ & $84.50 \mathrm{c}-\mathrm{e}$ & 87.47 & $\overline{a b}$ & \\
\hline & 60 & $84.92 \mathrm{c}-\mathrm{e}$ & $92.95 \mathrm{ab}$ & $86.1 \mathrm{c}-\mathrm{e}$ & $92.57 \mathrm{ab}$ & 89.13 & $a$ & \\
\hline
\end{tabular}




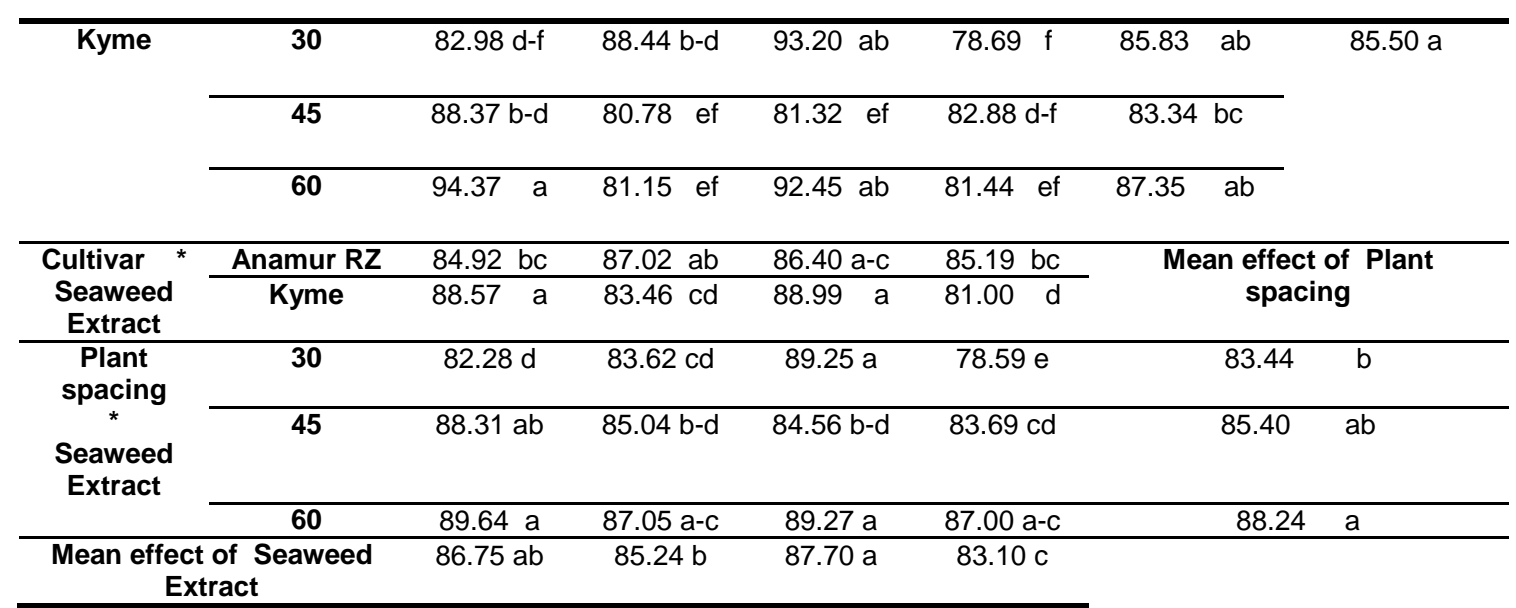

*Means within a rows, columns and their interaction written with the same letters are not significantly different from each other according to Duncan's multiple range test at $5 \%$ level.

\section{Chlorophyll content in leaves (SPAD):}

Results in the table (3) showed that the cultivars not affected on the chlorophyll content in leaves. The plant spacing significantly influenced on the chlorophyll in leaves, at level $(60 \mathrm{~cm})$ spacing the plants gave the highest value (55.83). Also the chlorophyll content in leaves significantly affected by seaweed extract and the maximum results was achieved by applying $\left(1 \mathrm{ml} . \mathrm{l}^{-1}\right)$ of seaweed extract which was (54.00).

Interaction between cultivars and plant spacing was superior in Kyme cultivars and (60 $\mathrm{cm})$ spacing. Also interaction between cultivars and seaweed extract significantly improved chlorophyll in leaves, the highest result was recorded in the Kyme cultivars and $\left(1 \mathrm{ml}^{\mathrm{l}^{-1}}\right)$ of seaweed extract (56.47). Interaction between plant spacing and seaweed extract gave a significant impact on chlorophyll in leaves, the maximum value was measured in the combination between $(60 \mathrm{~cm})$ spacing and $(1$ $\left.\mathrm{ml} . \mathrm{l}^{-1}\right)$ of seaweed extract. The interaction among all factors (cultivars, plant spacing and seaweed extract) was found significantly enhanced chlorophyll content in leaves. The highest value was achieved in the interaction among Kyme cultivar, $(60 \mathrm{~cm})$ spacing and spraying $\left(1 \mathrm{ml}^{-1} \mathrm{l}^{-1}\right)$ of seaweed

extract.

Table (3): Effect of cultivars, planting spacing, seaweed extract and their interaction on Chlorophyll

\begin{tabular}{|c|c|c|c|c|c|c|c|}
\hline \multirow[t]{2}{*}{ Cultivars } & \multirow{2}{*}{$\begin{array}{c}\text { Plant } \\
\text { spacing }\end{array}$} & \multicolumn{4}{|c|}{ Seaweed Extract } & \multirow{2}{*}{$\begin{array}{l}\text { Cultivar } \\
\text { * Plant } \\
\text { spacing }\end{array}$} & \multirow{2}{*}{$\begin{array}{l}\text { Mean effect } \\
\text { of cultivars }\end{array}$} \\
\hline & & 0 & 0.5 & 1 & 1.5 & & \\
\hline \multirow[t]{3}{*}{ Anamur RZ } & 30 & $51.52 \mathrm{f}-\mathrm{h}$ & $50.19 \mathrm{gh}$ & $51.61 \mathrm{f}-\mathrm{h}$ & $50.21 \mathrm{gh}$ & $50.88 \mathrm{~cd}$ & \multirow[t]{3}{*}{$51.23 \mathrm{a}$} \\
\hline & 45 & $50.31 \mathrm{gh}$ & $51.12 \mathrm{f}-\mathrm{h}$ & $49.65 \mathrm{gh}$ & $49.59 \mathrm{gh}$ & $50.17 d$ & \\
\hline & 60 & $52.85 d-h$ & 52.47 e-h & $53.30 \mathrm{~d}-\mathrm{g}$ & $51.97 \mathrm{e}-\mathrm{h}$ & $52.65 \mathrm{bc}$ & \\
\hline \multirow[t]{3}{*}{ Kyme } & 30 & $51.35 \mathrm{f}-\mathrm{h}$ & 51.93 e-h & $53.22 \mathrm{~d}-\mathrm{g}$ & $48.75 \mathrm{~h}$ & $51.31 \mathrm{~cd}$ & \multirow[t]{3}{*}{$54.94 \mathrm{a}$} \\
\hline & 45 & $55.77 \mathrm{c}-\mathrm{e}$ & $53.77 \mathrm{~d}-\mathrm{g}$ & $54.95 c-f$ & $53.49 \mathrm{~d}-\mathrm{g}$ & $54.49 \mathrm{~b}$ & \\
\hline & 60 & $58.40 \mathrm{a}-\mathrm{c}$ & $59.58 \mathrm{ab}$ & $61.24 \mathrm{a}$ & 56.82 b-d & $59.01 \mathrm{a}$ & \\
\hline \multirow{2}{*}{$\begin{array}{c}\text { Cultivar } \\
\text { Seaweed } \\
\text { Extract }\end{array}$} & Anamur RZ & $51.56 \mathrm{bc}$ & $51.26 \mathrm{bc}$ & $51.52 \mathrm{bc}$ & $50.59 \mathrm{c}$ & \multirow{2}{*}{\multicolumn{2}{|c|}{$\begin{array}{l}\text { Mean effect of Plant } \\
\text { spacing }\end{array}$}} \\
\hline & Kyme & $55.17 \mathrm{a}$ & $55.09 \mathrm{a}$ & $56.47 \mathrm{a}$ & $53.02 \mathrm{~b}$ & & \\
\hline $\begin{array}{c}\text { Plant } \\
\text { spacing }\end{array}$ & 30 & 51.44 ef & 51.06 ef & $52.42 \mathrm{de}$ & $49.48 \mathrm{f}$ & \multicolumn{2}{|c|}{$51.10 \mathrm{~b}$} \\
\hline
\end{tabular}




\begin{tabular}{ccccccc}
\hline \multirow{2}{*}{$\begin{array}{c}\text { Seaweed } \\
\text { Extract }\end{array}$} & 45 & $53.04 \mathrm{c}-\mathrm{e}$ & $52.45 \mathrm{de}$ & $52.30 \mathrm{de}$ & $51.54 \mathrm{ef}$ & $52.33 \mathrm{~b}$ \\
\cline { 2 - 6 } & 60 & $55.63 \mathrm{a}-\mathrm{c}$ & $56.02 \mathrm{ab}$ & $57.27 \mathrm{a}$ & $54.40 \mathrm{~b}-\mathrm{d}$ & $55.83 \mathrm{a}$ \\
\hline $\begin{array}{c}\text { Mean effect of Seaweed } \\
\text { Extract }\end{array}$ & $53.37 \mathrm{a}$ & $53.18 \mathrm{ab}$ & $54.00 \mathrm{a}$ & $51.81 \mathrm{~b}$ & \\
\hline
\end{tabular}

*Means within a rows, columns and their interaction written with the same letters are not significantly different from each other according to Duncan's multiple range test at 5\% level.

\section{Fruit and Yield characteristics:}

\section{Average Fruits Weight (g. fruit- ${ }^{1}$ ):}

Table (4) revealed that the average fruit weight are significantly variant in the two cultivars and the Kyme cultivars was superior by $\left(126.45 \mathrm{~g}\right.$. fruit $\left.{ }^{-1}\right)$. The effect of plant spacing shows that there were no significant differences between treatment in average fruit weight. The influences of seaweed extract recorded a significant improved in concentration $\left(0.5 \mathrm{ml}^{-1^{-1}}\right)$ and $\left(1 \mathrm{ml}^{-1^{-1}}\right)$ at rate $\left(114.56 \mathrm{~g}\right.$. fruit ${ }^{-}$ ${ }^{1}$ and $113.15 \mathrm{~g}$. fruit ${ }^{-1}$ ) respectively. Interaction between cultivars and plant spacing, there were a significant differences between them, the highest value was recorded in Kyme cultivars and (45 $\mathrm{cm}$ ) spacing. The interaction between cultivars and seaweed extract the best value was recorded in the interaction between the Kyme cultivars and $\left(0.5 \mathrm{ml} . \mathrm{l}^{-1}\right)$ of seaweed extract. The influence of plant spacing and seaweed extract significantly enhanced average fruit weight at level $(45 \mathrm{~cm})$ spacing and $\left(0.5 \mathrm{ml}^{-1} \mathrm{l}^{-1}\right)$ seaweed extract, with the maximum weight (118.70 g. fruit ${ }^{-1}$ ). The interaction among the three factors shows a significant differences between them, the highest number was recorded in interaction among Kyme cultivars, $(45 \mathrm{~cm})$ spacing and $\left(0.5 \mathrm{ml}^{-\mathrm{l}^{-1}}\right)$ of seaweed extract in comparison to all other treatments.

Table (4): Effect of cultivars, plant spacing, seaweed extract and their interaction on average fruit

\begin{tabular}{|c|c|c|c|c|c|c|c|}
\hline \multirow[t]{2}{*}{ Cultivars } & \multirow{2}{*}{$\begin{array}{c}\text { Plant } \\
\text { spacing }\end{array}$} & \multicolumn{4}{|c|}{ Seaweed Extract } & \multirow{2}{*}{$\begin{array}{c}\text { Cultivar * } \\
\text { Plant } \\
\text { spacing }\end{array}$} & \multirow{2}{*}{$\begin{array}{c}\text { Mean } \\
\text { effect of } \\
\text { cultivars }\end{array}$} \\
\hline & & 0 & 0.5 & 1 & 1.5 & & \\
\hline \multirow[t]{3}{*}{ Anamur RZ } & 30 & $88.42 \mathrm{f}$ & $94.84 \mathrm{f}$ & 97.88 ef & $96.12 \mathrm{f}$ & $94.31 \quad b$ & $94.52 \mathrm{~b}$ \\
\hline & 45 & $86.26 f$ & 98.78 ef & 97.30 ef & $95.10 \mathrm{f}$ & $94.36 \quad b$ & \\
\hline & 60 & $88.04 \mathrm{f}$ & 98.46 ef & 99.74 ef & $93.31 \mathrm{f}$ & $94.89 \mathrm{~b}$ & \\
\hline \multirow[t]{3}{*}{ Kyme } & 30 & $117.31 \mathrm{~cd}$ & 129.20a-c & 126.03a-d & 124.04 a-d & $124.16 \mathrm{a}$ & $126.45 \mathrm{a}$ \\
\hline & 45 & $134.68 \mathrm{ab}$ & $138.62 \mathrm{a}$ & 125.33a-d & $122.86 \mathrm{~b}-\mathrm{d}$ & $130.37 \mathrm{a}$ & \\
\hline & 60 & $111.97 \mathrm{de}$ & 127.42a-d & $132.62 a-c$ & $127.32 \mathrm{a}-\mathrm{d}$ & $124.83 \mathrm{a}$ & \\
\hline \multirow[t]{2}{*}{$\begin{array}{c}\text { Cultivar }{ }^{*} \\
\text { Seaweed Extract }\end{array}$} & $\begin{array}{l}\text { Anamur } \\
\text { RZ }\end{array}$ & $87.57 \mathrm{~d}$ & $97.36 \mathrm{c}$ & $98.31 \mathrm{c}$ & $94.84 \mathrm{~cd}$ & \multirow{2}{*}{\multicolumn{2}{|c|}{$\begin{array}{l}\text { Mean effect of Plant } \\
\text { spacing }\end{array}$}} \\
\hline & Kyme & $121.32 \mathrm{~b}$ & $131.77 \mathrm{a}$ & $127.99 \mathrm{ab}$ & $124.74 \mathrm{ab}$ & & \\
\hline \multirow{3}{*}{$\begin{array}{ll} & \text { Plant spacing } \\
\star & \text { Seaweed Extract }\end{array}$} & 30 & $102.86 \mathrm{bc}$ & $112.05 a b$ & $111.95 a b$ & 110.08 a-c & \multicolumn{2}{|c|}{$109.24 \mathrm{a}$} \\
\hline & 45 & $110.47 \mathrm{a}-\mathrm{c}$ & $118.70 \mathrm{a}$ & $111.31 \mathrm{ab}$ & 108.98 a-c & \multicolumn{2}{|c|}{$112.37 \mathrm{a}$} \\
\hline & 60 & $100.01 \mathrm{c}$ & $112.94 \mathrm{ab}$ & $116.18 \mathrm{a}$ & $110.31 \mathrm{a}-\mathrm{c}$ & \multicolumn{2}{|c|}{$109.86 \mathrm{a}$} \\
\hline
\end{tabular}

Mean effect of Seaweed Extract $104.45 \mathrm{~b}$
*Means within a rows, columns and their interaction written with the same letters are not
significantly different from each other according to Duncan's multiple range test at 5\% level

significantly different from each other according to Duncan's multiple range test at $5 \%$ level. 


\section{Plant Yield (kg. Plant $\left.{ }^{-1}\right)$ :}

Data in table (5) indicated that there was a significant difference between the two cultivars on plant yield, the best value was obtained in Kyme cultivar $\left(3.43 \mathrm{~kg}\right.$. Plant $\left.{ }^{-1}\right)$. The plant spacing significantly influenced in plant yield, the highest number recorded in $(60 \mathrm{~cm})$ spacing at $\left(3.96 \mathrm{~kg}\right.$. Plant $\left.{ }^{-1}\right)$. Spraying with seaweed extract showed a significant effect on plant yield, the level $(1 \mathrm{ml} / \mathrm{L})$ gave the highest results, when comparing with concentration $\left(0.5 \mathrm{ml}^{-1} \mathrm{l}^{-1}\right)$ which was (3.31 kg. Plant $\left.{ }^{-1}\right)$.

Interaction between cultivars and plant spacing showed a significant differences among them, the superior interaction was recorded in Kyme cultivar and $(60 \mathrm{~cm})$ spacing. Also interaction between cultivars and seaweed extract recorded a significant influences on plant yield, the concentration $\left(1 \mathrm{ml} . \mathrm{l}^{-1}\right)$ of seaweed extract and Kyme cultivar had the highest value. The interaction between plant spacing and seaweed extract resulted in significant impact between them, the maximum value was measured in the combination between $(60 \mathrm{~cm})$ spacing and $\left(0.5 \mathrm{ml} . \mathrm{l}^{-1}\right)$ of seaweed ,also $(60 \mathrm{~cm})$ spacing and $\left(1 \mathrm{ml}^{-1^{-1}}\right)$ of seaweed extract respectively.

In the triple interaction results revealed that there were a significant differences among the three factors in plant yield, the Kyme cultivar, $(60 \mathrm{~cm})$ spacing and $\left(1 \mathrm{ml}^{-\mathrm{l}^{-1}}\right)$ of seaweed extract positively improved plant yield.

Table (5): Effect of cultivars, planting spacing, seaweed extract and their interaction on plant yield (kg. Plant ${ }^{-1}$ ) of eggplant.*

\begin{tabular}{|c|c|c|c|c|c|c|c|}
\hline \multirow[t]{2}{*}{ Cultivars } & \multirow{2}{*}{$\begin{array}{c}\text { Plant } \\
\text { spacing }\end{array}$} & \multicolumn{4}{|c|}{ Seaweed Extract } & \multirow{2}{*}{$\begin{array}{c}\text { Cultivar } \\
\text { Plant } \\
\text { spacing }\end{array}$} & \multirow{2}{*}{$\begin{array}{l}\text { Mean } \\
\text { effect of } \\
\text { cultivars }\end{array}$} \\
\hline & & 0 & 0.5 & 1 & 1.5 & & \\
\hline \multirow[t]{3}{*}{ Anamur RZ } & 30 & $1.91 \mathrm{~m}$ & $2.06 \mathrm{~m}$ & $2.49 \mathrm{k}$ & $2.07 \mathrm{~m}$ & $2.13 \mathrm{e}$ & $2.99 \mathrm{~b}$ \\
\hline & 45 & $2.62 \mathrm{jk}$ & $3.11 \mathrm{i}$ & $3.04 \mathrm{i}$ & $2.97 \mathrm{i}$ & $2.93 \mathrm{c}$ & \\
\hline & 60 & $3.89 \mathrm{de}$ & $4.28 \mathrm{~b}$ & 3.80 ef & $3.62 \mathrm{~g}$ & $3.90 \mathrm{~b}$ & \\
\hline \multirow[t]{3}{*}{ Kyme } & 30 & $2.51 \mathrm{k}$ & $2.47 \mathrm{k}$ & $2.68 \mathrm{j}$ & $2.30 \quad 1$ & $2.49 \mathrm{~d}$ & $3.43 \mathrm{a}$ \\
\hline & 45 & $3.99 \mathrm{~cd}$ & $3.85 \mathrm{de}$ & $3.68 \mathrm{fg}$ & $3.59 \mathrm{~g}$ & $3.78 \mathrm{~b}$ & \\
\hline & 60 & $3.36 \mathrm{~h}$ & $4.09 \mathrm{c}$ & $4.48 \mathrm{a}$ & $4.15 \mathrm{bc}$ & $4.02 \mathrm{a}$ & \\
\hline \multirow{2}{*}{$\begin{array}{c}\text { Cultivar } \\
\text { Seaweed } \\
\text { Extract }\end{array}$} & $\begin{array}{c}\text { Anamur } \\
\text { RZ }\end{array}$ & $2.80 \mathrm{e}$ & $3.15 \mathrm{~d}$ & $3.11 \mathrm{~d}$ & $2.89 \mathrm{e}$ & \multirow{2}{*}{\multicolumn{2}{|c|}{$\begin{array}{l}\text { Mean effect of Plant } \\
\text { spacing }\end{array}$}} \\
\hline & Kyme & $3.29 \mathrm{c}$ & $3.47 \mathrm{~b}$ & $3.61 \mathrm{a}$ & $3.35 \mathrm{c}$ & & \\
\hline \multirow{3}{*}{$\begin{array}{c}\text { Plant } \\
\text { spacing } \\
\star \\
\text { Seaweed } \\
\text { Extract }\end{array}$} & 30 & $2.21 \mathrm{~g}$ & $2.27 \mathrm{~g}$ & $2.58 \mathrm{f}$ & $2.18 \mathrm{~g}$ & \multicolumn{2}{|c|}{$2.31 \mathrm{c}$} \\
\hline & 45 & $3.30 \mathrm{e}$ & $3.48 \mathrm{~d}$ & $3.36 \mathrm{e}$ & $3.28 \mathrm{e}$ & \multicolumn{2}{|c|}{$3.36 \mathrm{~b}$} \\
\hline & 60 & $3.62 \mathrm{c}$ & $4.19 \mathrm{a}$ & $4.14 \mathrm{a}$ & $3.88 b$ & \multicolumn{2}{|c|}{$3.96 \mathrm{a}$} \\
\hline \multicolumn{2}{|c|}{$\begin{array}{c}\text { Mean effect of Seaweed } \\
\text { Extract }\end{array}$} & $3.05 \mathrm{c}$ & $3.31 \mathrm{a}$ & $3.36 \mathrm{a}$ & $3.12 b$ & & \\
\hline
\end{tabular}

*Means within a rows, columns and their interaction written with the same letters are not significantly different from each other according to Duncan's multiple range test at $5 \%$ level. 


\section{Total Yield (ton. ha' $\left.{ }^{-1}\right)$ :}

Table (6) revealed that there were significant variation between the cultivars in the total yield, the Kyme cultivar gave the superior value (77.95 ton. ha $\left.{ }^{-1}\right)$. The influence of plant spacing significantly improved plant yield with $(30 \mathrm{~cm})$ spacing by $\left(77.02\right.$ ton. hectare $\left.{ }^{-1}\right)$. The seaweed extract significantly affected on total yield, obvious that the concentration $\left(1 \mathrm{ml}^{-1} \mathrm{l}^{-1}\right)$ of seaweed extract promoted total yield by $(76.53$ ton. hectare $\left.{ }^{-1}\right)$.

Binary interaction refers that the interaction between Kyme cultivars and $(45 \mathrm{~cm})$ plant spacing obtained the best value. The combination between Kyme cultivars and (1 $\mathrm{ml} / \mathrm{L}$ ) of seaweed extract gave the highest result. Also the interaction between plant spacing and seaweed extract shows a significant differences between them, the highest value was recorded from $(30 \mathrm{~cm})$ spacing and $\left(1 \mathrm{ml}^{-1} \mathrm{l}^{-1}\right)$ of seaweed. Regarding the interaction among the three factors, there were a significant differences between them. The best results were recorded in combination of Kyme cultivar, $(30 \mathrm{~cm})$ spacing and $\left(1 \mathrm{ml} . \mathrm{l}^{-1}\right)$ of seaweed extract.

Table (6): Effect of cultivars, plant spacing, seaweed extract and their interaction on total yield (ton. ha $^{-1}$ ) of eggplant. *

\begin{tabular}{|c|c|c|c|c|c|c|c|c|}
\hline \multirow[t]{2}{*}{ Cultivars } & \multirow{2}{*}{$\begin{array}{l}\text { Plant } \\
\text { spacing }\end{array}$} & \multicolumn{4}{|c|}{ Seaweed Extract } & \multirow{2}{*}{$\begin{array}{l}\text { Cultivar } \\
\text { Plant } \\
\text { spacing }\end{array}$} & & \multirow{2}{*}{$\begin{array}{c}\text { Mean } \\
\text { effect of } \\
\text { cultivars }\end{array}$} \\
\hline & & 0 & 0.5 & 1 & 1.5 & & & \\
\hline \multirow[t]{3}{*}{ Anamur RZ } & 30 & $63.72 \mathrm{kl}$ & $68.80 \mathrm{hi}$ & $82.84 \mathrm{~cd}$ & $69.13 \mathrm{hi}$ & $71.12 \mathrm{~b}$ & & \multirow[t]{3}{*}{$67.09 \mathrm{~b}$} \\
\hline & 45 & $58.12 \mathrm{mn}$ & $69.16 \mathrm{hi}$ & 67.46 ij & $66.08 \mathrm{i}-\mathrm{k}$ & $65.20 \mathrm{c}$ & & \\
\hline & 60 & $64.77 \mathrm{jk}$ & $71.38 \mathrm{gh}$ & $63.33 \mathrm{kl}$ & $60.34 \mathrm{Im}$ & $64.95 \mathrm{c}$ & & \\
\hline \multirow[t]{3}{*}{ Kyme } & 30 & $83.60 \mathrm{~cd}$ & $82.28 \mathrm{~cd}$ & $89.25 \mathrm{a}$ & 76.50 ef & $82.91 \mathrm{a}$ & & \multirow[t]{3}{*}{77.95 a } \\
\hline & 45 & $88.65 \mathrm{ab}$ & $85.63 \mathrm{bc}$ & $81.67 \mathrm{~d}$ & 79.86 de & $83.95 \mathrm{a}$ & & \\
\hline & 60 & $56.04 n$ & $68.21 \mathrm{~h}-\mathrm{j}$ & $74.62 \mathrm{fg}$ & $69.13 \mathrm{hi}$ & $67.00 \mathrm{c}$ & $c$ & \\
\hline \multirow{2}{*}{$\begin{array}{c}\text { Cultivar * } \\
\text { Seaweed } \\
\text { Extract }\end{array}$} & $\begin{array}{c}\text { Anamur } \\
\text { RZ }\end{array}$ & $62.21 \mathrm{f}$ & $69.78 \mathrm{~d}$ & $71.21 \mathrm{~d}$ & $65.18 \mathrm{e}$ & \multirow{2}{*}{\multicolumn{3}{|c|}{$\begin{array}{l}\text { Mean effect of Plant } \\
\text { spacing }\end{array}$}} \\
\hline & Kyme & $76.10 \mathrm{c}$ & $78.71 \mathrm{~b}$ & $81.85 \mathrm{a}$ & $75.16 \mathrm{c}$ & & & \\
\hline \multirow{3}{*}{$\begin{array}{c}\text { Plant } \\
\text { spacing } \\
\star \\
\text { Seaweed } \\
\text { Extract }\end{array}$} & 30 & $73.66 \mathrm{c}$ & 75.54 bc & $86.05 \mathrm{a}$ & $72.82 \mathrm{c}$ & \multicolumn{3}{|c|}{$77.02 \mathrm{a}$} \\
\hline & 45 & $73.39 \mathrm{c}$ & $77.39 \mathrm{~b}$ & $74.56 \mathrm{c}$ & $72.97 \mathrm{c}$ & \multicolumn{3}{|c|}{$74.58 \mathrm{~b}$} \\
\hline & 60 & $60.41 \mathrm{f}$ & $69.80 \mathrm{~d}$ & $68.98 \mathrm{~d}$ & $64.73 \mathrm{e}$ & \multicolumn{3}{|c|}{$65.98 \mathrm{c}$} \\
\hline \multicolumn{2}{|c|}{$\begin{array}{c}\text { Mean effect of Seaweed } \\
\text { Extract }\end{array}$} & $69.15 \mathrm{c}$ & $74.24 \mathrm{~b}$ & $76.53 \mathrm{a}$ & $70.17 \mathrm{c}$ & & & \\
\hline
\end{tabular}

* Means within a rows, columns and their interaction written with the same letters are not significantly different from each other according to Duncan's multiple range test at 5\% level.

\section{4- DISCUSSION}

1. Effect of cultivars, plant spacing and seaweed extract on vegetative characteristics:

The results from table (1,2 and 3) revealed that the studied factors (cultivars, plant spacing and seaweed extract) and their interaction have a significant influences on most parameters. Cultivars has a significant effect on plant height, but it not affected on leaf area and chlorophyll in leaves. The variation in plant height between the two cultivars may be due to the increases in 
nutrient absorption in the soil by Anamur RZ cultivars rather than Kyme cultivars or may be due to the variation in the root system or the genetic differences between the two cultivars, the same results were reported by (Ibraheim and Mohsen, 2016; Rasheed et al, 2017 ; Rasheed, 2013 and Olaniyi et al, 2010).

The using of plant spacing in the studies showed the pervious results in table (1,2 and 3$)$ which indicated that there were a significant differences among treatment in plant height, leaf area and chlorophyll in leaves. The positive effect of plant spacing may be due to various factors. The plants with wider plant spacing take more resources like light, water and nutrients from soil as compared to the lower planting density, as a result to competition among them. These results are acceptable with that reported by (Alabi et al., 2014) which said that could be attributed to the competition among plants to the available water, nutrients from soil and photosynthetically active radiation in the lowest planting density. Also the data obtained are agreed with (Ibraheim and Mohsen, 2016; Ndereyimana et al. 2014).

The enhancement of vegetative growth by application of seaweed extract resulted in significant effect in some parameters like leaf area and chlorophyll content in leaves. This significant effect may be returned to the positive effect of seaweed extract on plant growth which contain major macronutrients, plant growth hormones (auxin, Gibberellins and cytokines), also the plant biostimulants such as vitamins and amino acids, as well as improve plants resistances and delay plant senescence. These results are acceptable with that reported by (Abd El-Gawad and Osman, 2014; Hegazi, $\boldsymbol{e t}$ al, 2015; and Mohammed, 2013). However, the growth-enhancing of seaweed application may be attributed to the presence of carbohydrate and of micro and macro nutrient (Sangeetha and Thevanathan, 2010). Also seaweed extracts enhance the growth of vegetables and other crops as they contain plant growth regulators such as auxins (IAA and IBA), cytokinins, gibberellins and betaines (Kumar and Sahoo, 2011).

Vegetative growth improvement by seaweed extracts may be as a results of its components like macro and micro elements, vitamins, amino acids, auxins, cytokinins, and abssisic acid
(ABA) like growth regulators which influences in cellular metabolism in treated plants due to improve growth and yield, these results agreed with (Ordog et al. 2004 and Durand et al. 2003).

2. Effect of cultivars, plant spacing and seaweed extract on yield characteristics:

It obvious from tables $(4,5$ and 6$)$ that all factors (cultivars, planting density and seaweed extract) individually and combined increased the most studied parameter significantly, which are average fruit weight, plant yield and total yield.

The cultivars influences on eggplant crop may be due to the environmental conditions or genotypes. The same results was approved by (Shewfeld, 1999 and Maniutiu et al., 2008) which are revealed that Genetic factors and environmental conditions, including nutrients content in the soil are the major factors affecting on vegetable crops. Various cultivars of eggplant have different growth habit which reflect on yield productivity (Mohammed, 2015). The results are in acceptable with (Ibraheim and Mohsen, 2016) which are showed that the variability between the cultivars could be as a result of the different genetic factors among them. So in this research Kyme cultivar gave the highest value in all yield characteristics.

It is clear from the tables (4, 5 and 6$)$ that plant spacing significantly Increases the plant yield and total yields in the term of yield characteristics, but not affected on average fruit weight. The plant spacing at rate $(60 \mathrm{~cm})$ significantly increased the plant yield, while the plant spacing $(30 \mathrm{~cm})$ increases the total yield, that results are obtained as a results of competition between plants for the recourses like nutrient, water and light. These results are agreed with (Rasheed, 2013; Ibraheim and Mohsen, 2016; and Islam et al., 2011). However, the highest plant yield was obtained with maximum plant spacing and thus increases the number of plants per unit area, which increase the numbers of fruits per hectare which may lead to the increase in production (Cavero et al, 2001).

Seaweed extract significantly affected in the yield characteristics like average fruit weight, plant yield and total yield, which are mentioned in the results in table (4,5 and 6). The 
improvements in yields may be associated with the increase in vegetative growth parameters which previously mentioned in table (1,2 and 3), these results are agreed with (El-Miniawy $\boldsymbol{e t}$ al, 2014; Mohammed, 2013 and Al-Saaberi, 2005). Also the enhancement of yield may be due to the presence of plant growth regulators in the seaweeds extract, especially Cytokinins. Cytokinins in vegetative plant parts are related with nutrient apportionment, while in reproductive organs, high percent of cytokinins may be associated with nutrient mobilization

\section{(Abd El-Gawad and Osman, 2014).}

\section{Conclusion:}

According the pervious results the three factors (Cultivars, Plant spacing and Seaweed extract) have positive effect on plant growth and yield parameters. The Kyme cultivar has a superiority over Anamur RZ cultivar in almost all parameters. The spacing have significant effect on plant growth and yield parameters. The spraying of seaweed extract at concentration $\left(1 \mathrm{ml}^{-l^{-1}}\right)$ gave the best results.

\section{References:}

Abd El-Gawad, H.G. and Osman, H.S. (2014). Effect of Exogenous Application of Boric Acid and Seaweed Extract on Growth, Biochemical Content and Yield of Eggplant. Journal of Horticultural Science \& Ornamental Plants. 6 (3): 133-143.

Adani, F.P., Genevini,P., Zaccheo, P. and Zocchi, G. (1998). The effect of commercial humic acid on tomato plant growth and mineral nutrition. J. Plant Nutr., 21(3): 561-575.

Alabi, E. O., Ayodele, O. J. and Aluko, M. (2014). Growth and yield responses of bell pepper (Capsicum annuum, Rodo'Variety) to in- row plant spacing. ARPN J. Agric. and Biol. Sci. 9(11): 389-397.

Al-Saaberi, M.R.S. (2005). Effect of some agricultural treatments on growth, yield of lettuce (Lactuca sativa L.), M.Sc. Thesis, , Horticulture Sciences University of Mosul College of Agriculture and Forestry.

Arun, B.A. (2013). Studies On Spacing And Fertilizer Levels On Growth And Yield Of Brinjal (Solanum melongena L.) Hybrid "Phule Arjun". Maharashtra State, India.
Battacharyya, D., Babgohari, M.Z., Rathor, P. And Prithiviraj, B. (2015). Seaweed extracts as biostimulants in horticulture. Scientia Horticulturae. 196. Pp: 39-48.

Bozorgi, H.R. (2012). Effects of foliar spraying with marine plant Ascophyllum nodosum extract and nano iron chelate fertilizer on Fruit yield and several attributes of eggplant (Solanum melongena L.). ARPN Journal of Agricultural and Biological Science. Vol. 7, No. 5.

Cavero, J., Ortega Gill, R. and Gutierrez, M. (2001). Plant density affects yield, yield components and colour of direct-seed paprika pepper. J. Hort. Sci.361(1): 76-79.

Chen, N.C. And Li, H.M. (2000). Cultivation And Breeding Of Eggplant. Asian Vegetable Research and Development Center . Shanhua, Tainan, Taiwan. Available on website: http://203.64.245.61/fulltext_pdf/eam0137.pdf

Das, S., Mandal, A. And Hazra, P. (2010) . Genetic diversity in brinjal genotypes under eastern Indian conditions. Indian Journal of Horticulture 67 (4): 166-169.

Durand,N., Briand, X. And Meyer, C. (2003) The effect of marine bioactive substances (NPRO) and exogenous cytokinins on nitrate reductase activity in Arabidopsis thaliana. Physiol Plant 119:489-493.

El-Miniawy, S.M., Ragab, M.E., Youssef, S.M. and Metwally, A.A. (2014). Influence of Foliar Spraying of Seaweed Extract on Growth, Yield and Quality of Strawberry Plants. Journal of Applied Sciences Research. 10(2): pages 88-94.

Hegazi, A. M., El-Shraiy, A, M. and Ghoname, A. A. (2015). Alleviation of Salt Stress Adverse Effect and Enhancing Phenolic Anti-oxidant Content of Eggplant by Seaweed Extract. Gesunde Pflanzen. 67:21-31.

Ibraheim, S. Kh. A. and Mohsen, A. A. M. (2016). Impact of Plant Spacing on Growth and Yield of Two Sweet Pepper Cultivars. Journal of American Science.12(11).

Islam, M., Saha, S., Akand, M.D. H. and Abdur Rahim, M.D. ( 2011). Effect of spacing on the growth and yield of sweet pepper (Capsicum annuum L.). J. Cent. Eur. Agric.12(2):328 335. 
Kantharajah, A. and Golegaonkar, P.(2004). Somatic embryogenesis in eggplant. Scientia Horticulturae 99 (2):107-117.

Khan, W., Rayirath, U.P., Subramanian, S., Jithesh, M.N., Rayorath, P., Hodges, D.M., Critchley, A.T., Craigie,J.S., Norrie,J. And Prithivira, B. (2009). Seaweed extracts as bio stimulants of plant growth and development", J. Plant Growth Regul., 28. Pp: 386-399.

Kumar, G. and Sahoo, D. (2011). Effect of seaweed liquid extract on growth and yield of Triticum aestivum var. Pusa Gold. Journal of Applied Phycology, 23(2): 251-255.

Maniutiu, D., Sima, R .and Ficior, D. (2008). The Influeance of Fructification Managing and Fertilization on Medium-Long Fruit Cucumber Hybrids Cultivated in Greenhouse. Not. Bot. Hort. Agrobot. Cluj-Napoca. 36(2):76-79.

Mohammed, G.H. (2013). Effect of Seamino and Ascorbic Acid on Growth, Yield and Fruits Quality of Pepper (Capsicum Annum L). International Journal of Pure and Applied Sciences and Technology. 17(2) pp. 9-16.

Mohammed, M.O. ( 2015). Effect of Planting Dates and Biofertilization on Growth Yield, and Yield Quantity of Three Okra Cultivars (Abelmoschus esculentus L.) Under Protective Conditions. MSc. Thesis. College of Agriculture, University of Duhok, Duhok, Iraq.

Muñoz-Falcón, J.E., Prohens, J., RodríguezBurruezo, A. And Nuez F. (2008). Potential of local varieties and their hybrids for the improvement of eggplant production in the open field and greenhouse cultivation. Journal of Food, Agriculture \& Environment. Vol.6 (1) $: 83-88$.
Ndereyimana, A., Praneetha, S., Pugalendhi, L., Pandian, B. J. And Hategekimana, A. (2014). Growth performance of Eggplant (Solanum melongena L.) Grafts Subjected to Different Spacing and Fertigation Levels. International Research Journal of Horticulture. 2(2):21-28.

Olaniyi J. O.; W. B. Akanbi; T. A. Adejumo and O. G. Akande (2010). Growth, fruit yield and nutritional quality of Tomato varieties. African J. of Food Science Vol. 4(6), pp. 398 - 402.

Ordog,V., Stirk,W.A., van Staden, J., Novak, O. And Strnad, M. (2004) Endogenous cytokinins in the three genera of macroalgae from the chlorophyta. J Phycol 40:88-95

Rasheed, S.M.S. (2013). Effect of Planting Density and Nutrient Foliar Spray on Growth, Yield and Yield Quality of Two Tomato Cultivars (Lycopersicon esculentum Mill.) Grown Under Plastic House Conditions. Ph.D. dissertation. College of agriculture, University of Duhok. Duhok, Iraq.

Rasheed, S.M.S., Abdullah, H.M. and Ali, S.T. (2017). Response of Two Hybrids of Tomato (Lycupersicun esculentum Mill) to Four Concentration of Humic Acid Fertilizers in Plastic House Condition. Journal Tikrit Univ. For Agri. Sci. Vol. ( 17 ) No.( 1 ).

Sangeetha,V. And Thevanathan, R. (2010) Biofertilizer potential of traditional and panchagavya amended with seaweed extract. J Amer Sci 6:61-67.

SAS programs (2003). Proprietary soft ware release, 6.12 TS Licensed to North Carolina state Univ. By SAS Institute Inc., Cary. USA.

Shewfelt, R. (1999). What is quality? Postharvest Biol. Technol. 15:197-2000. 


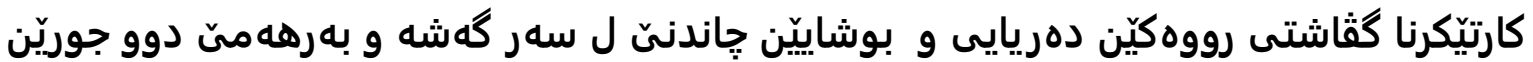

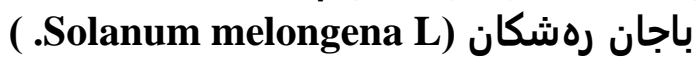

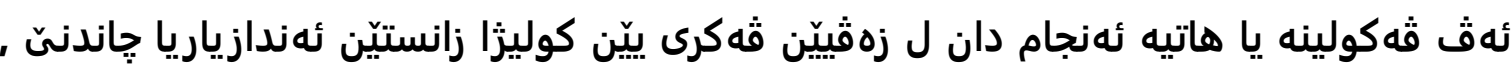

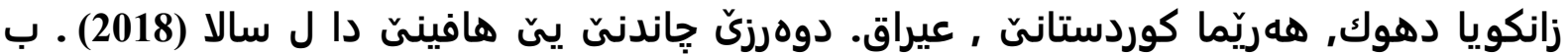

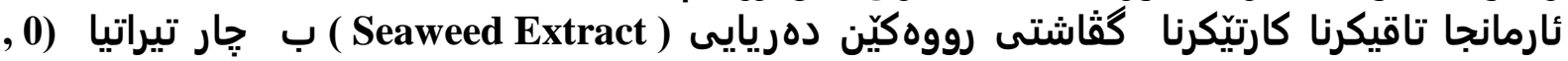

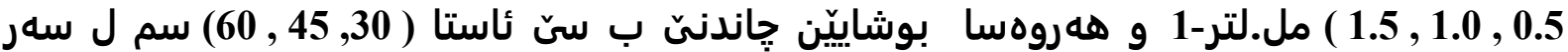

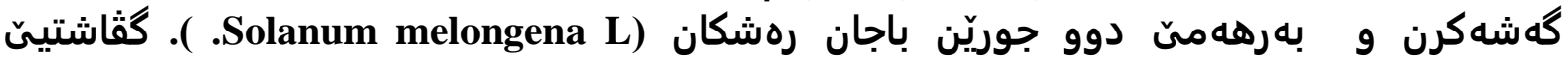

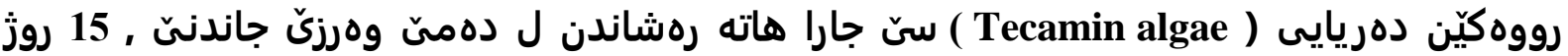

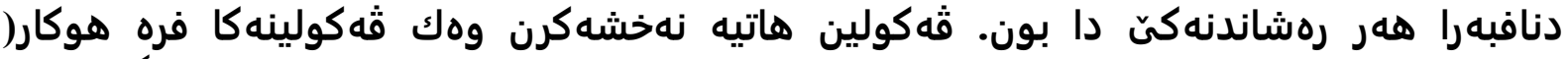

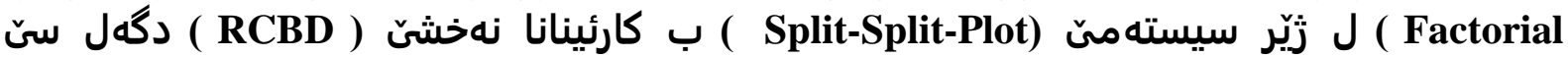

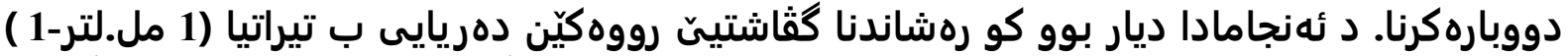

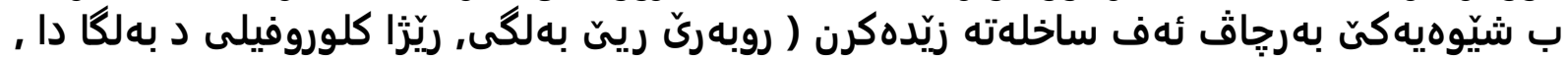

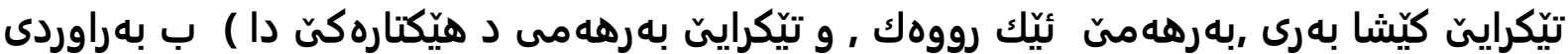

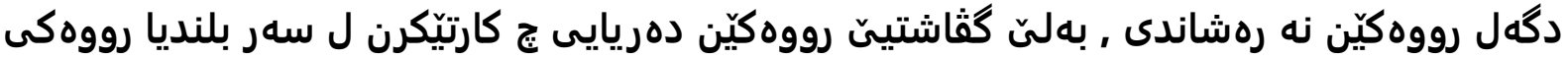

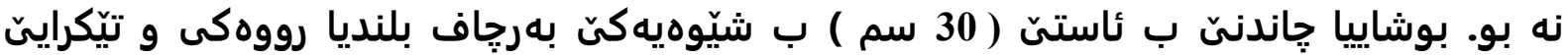

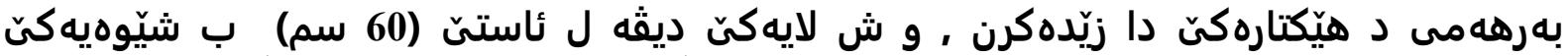

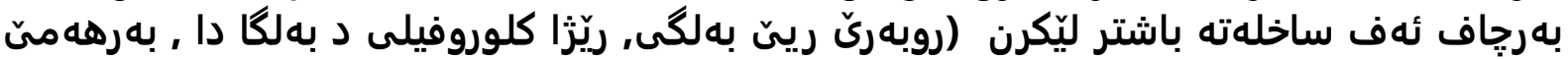

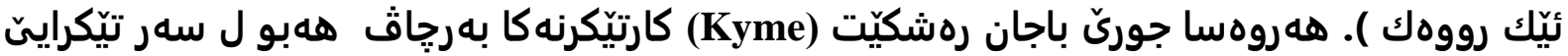

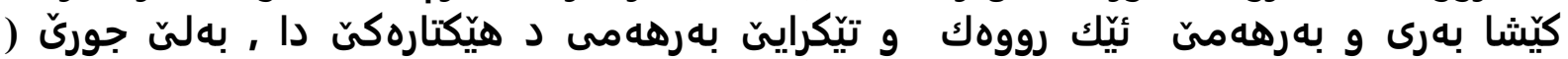

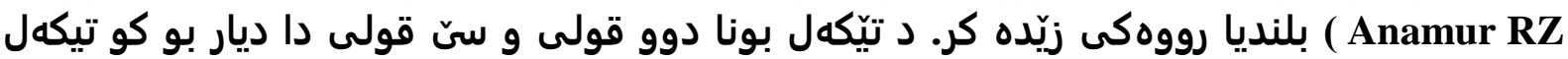

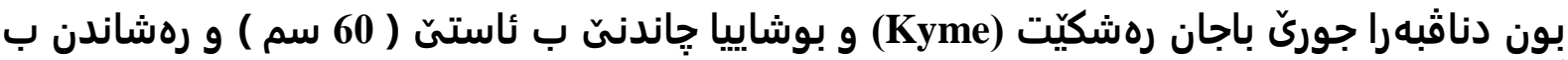

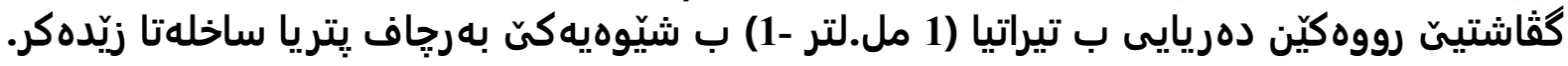

ثأثير مستخلص الأعشاب البحرية و المسافات الزراعية على نمو و حاصل صنفين من البادنجان ( Solanum melongena L.)

الخلاصة

نفذت الدراسة في الحقل المكشوف في حقول الخضراوات/كلية علوم الهندسة الزراعية

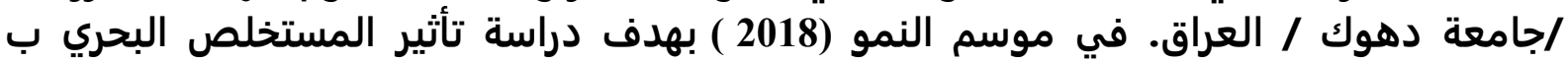




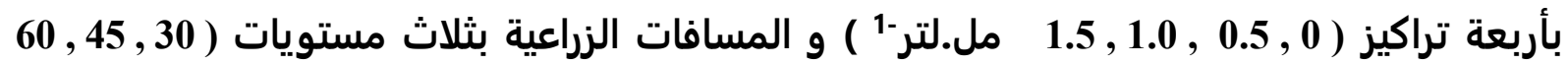

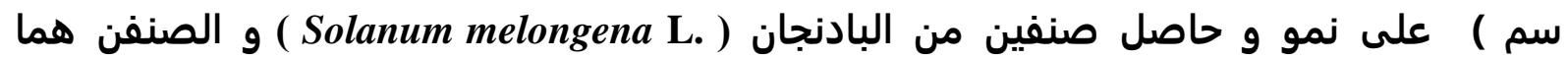
(Anamur RZ F1)

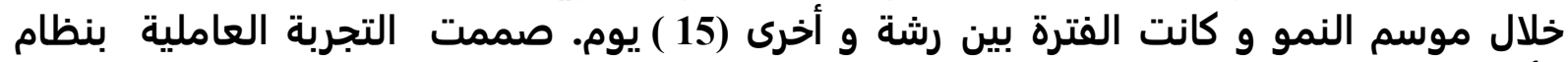

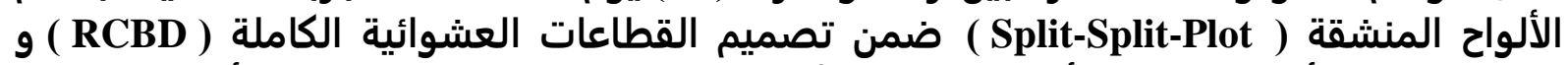

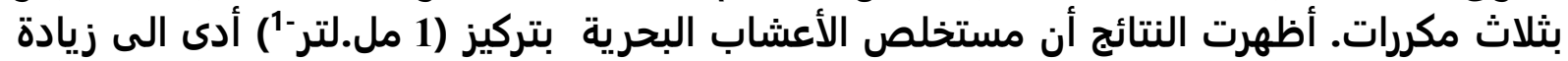

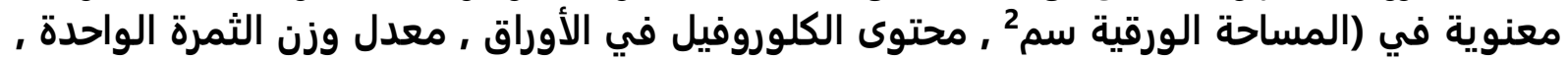

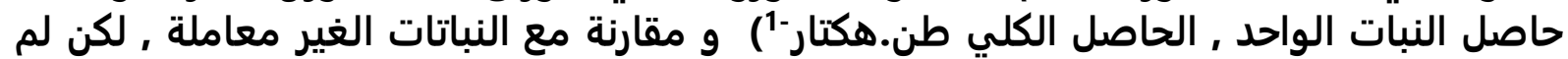

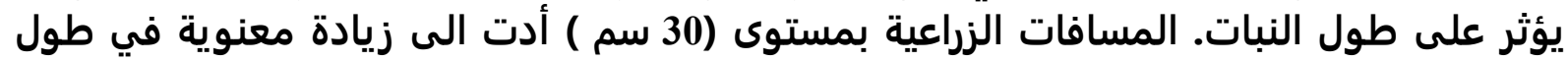

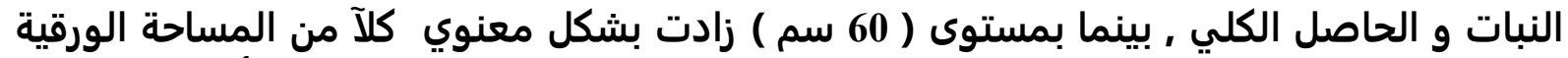

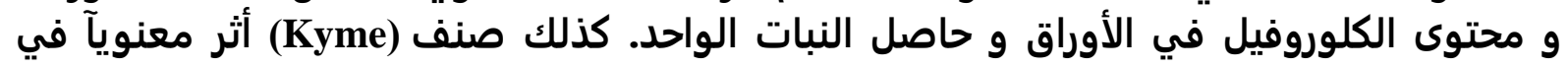

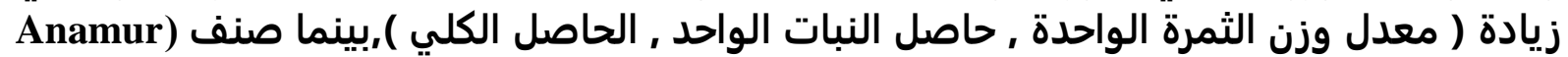
(RZ و المسافات الزراعية بمستوى (Kyme) 1 أدت الى زيادة معنوية في أغلب الصراعل الصفات. 